\title{
Article
}

\section{Low-Grade Clay as an Alkali-Activated Material}

\author{
Muhammad M. Rahman, David W. Law*(D), Indubhushan Patnaikuni, Chamila Gunasekara (D) and \\ Morteza Tahmasebi Yamchelou (iD
}

check for updates

Citation: Rahman, M.M.; Law, D.W.; Patnaikuni, I.; Gunasekara, C.;

Tahmasebi Yamchelou, M.

Low-Grade Clay as an

Alkali-Activated Material. Appl. Sci.

2021, 11, 1648. https://doi.org/10.

3390/app11041648

Academic Editor:

Joan Formosa Mitjans

Received: 8 January 2021

Accepted: 29 January 2021

Published: 12 February 2021

Publisher's Note: MDPI stays neutral with regard to jurisdictional claims in published maps and institutional affiliations.

Copyright: (c) 2021 by the authors. Licensee MDPI, Basel, Switzerland. This article is an open access article distributed under the terms and conditions of the Creative Commons Attribution (CC BY) license (https:// creativecommons.org/licenses/by/ $4.0 /)$.
Civil and Infrastructure Engineering, School of Engineering, RMIT University, Melbourne, Victoria 3000, Australia; mukhlesrhd@yahoo.com (M.M.R.); indu.patnaikuni@rmit.edu.au (I.P.); chamila.gunasekara@rmit.edu.au (C.G.); s3670466@student.rmit.edu.au (M.T.Y.)

* Correspondence: david.law@rmit.edu.au

\begin{abstract}
The potential application of alkali-activated material (AAM) as an alternative binder in concrete to reduce the environmental impact of cement production has now been established. However, as the production and availability of the primarily utilized waste materials, such as fly Ash and blast furnace slag, decrease, it is necessary to identify alternative materials. One such material is clay, which contains aluminosilicates and is abundantly available across the world. However, the reactivity of untreated low-grade clay can be low. Calcination can be used to activate clay, but this can consume significant energy. To address this issue, this paper reports the investigation of two calcination methodologies, utilizing low-temperature and high-temperature regimes of different durations, namely $24 \mathrm{~h}$ heating at $120^{\circ} \mathrm{C}$ and $5 \mathrm{~h}$ at $750{ }^{\circ} \mathrm{C}$ and, and the results are compared with those of the mechanical performance of the AAM produced with untreated low-grade clay. The investigation used two alkali dosages, $10 \%$ and $15 \%$, with an alkali modulus varying from 1.0 to 1.75 . An increase in strength was observed with calcination of the clay at both 120 and $750{ }^{\circ} \mathrm{C}$ compared to untreated clay. Specimens with a dosage of $10 \%$ showed enhanced performance compared to those with 15\%, with Alkali Modulus (AM) of 1.0 giving the optimal strength at 28 days for both dosages. The strengths achieved were in the range 10 to $20 \mathrm{MPa}$, suitable for use as concrete masonry brick. The conversion of $\mathrm{Al}$ (IV) is identified as the primary factor for the observed increase in strength.
\end{abstract}

Keywords: geopolymer; clay; compressive strength; alkali-activated material; mortar

\section{Introduction}

Alkali-activated materials (AAMs) have come in to use as substitute materials for ordinary Portland cement (OPC) in the construction industry in recent years. The use of AAM not only limits the emissions of contaminants but also consumes less energy and, thus, can play a major role in reducing the global warming problem [1-5]. Different types of raw materials, such as fly ash, kaolinite, palm oil fuel ash, rice husk ash, shale, natural zeolite, types of sludge, lignite bottom ash, natural fibers, red mud, and clay and clay minerals (including bentonite and montmorillonite), are currently being investigated as possible AAMs. Studies have shown that concrete made from different industrial waste material can display comparable or even better mechanical and durability properties than those associated with OPC concrete [6-14]. According to the reports of the Intergovernmental Panel on Climate Change $[3,15]$, the growth of world cement production increased sevenfold by 2010 compared to that in 1970, and from 2000, this growth has been increasing sharply driven by demand from the construction industry. It has been also reported that the cement industry was responsible for more than $13 \%$ of global emissions (emissions from cement-forming reactions only) of $\mathrm{CO}_{2}$ in 2010. The IPCC has also suggested using geopolymer concrete in place of OPC concrete to reduce $\mathrm{CO}_{2}$ emissions.

Research conducted to date has primarily focused on fly ash as a primary source of binder material. A concern is that fly ash production will decrease in the future as power generation switches from coal to other renewable forms of electricity production. It has also 
been reported that not all fly ash is suitable for geopolymer concrete production. Low-grade clay, which is a naturally occurring material that is abundant throughout the world, could be a suitable alternate source material to fulfil this requirement. Heath et al. suggested that there was the potential for global warming to be reduced by up to $40 \%$ if alkali-activated clay was used in place of OPC [4]. Perná et al. also identified the necessity for alternate substitute source materials for the production of geopolymer concrete [16]. Marsh et al. assessed the performance of uncalcinated montmorillonite and illite clays and reported a large variation in the properties, with montmorillonite displaying the more promising behavior [13]. Karouzou et al. investigated the long-term durability of alkali activation of soil samples with $13 \%$ clay particles, and the alkali-activated material demonstrated improved mechanical performance [14]. However, research on the utilization of low-grade clay as an alternative material for geopolymerization system is still in its infancy.

Research into clay-based geopolymers has reported strengths in the range of 5-40 MPa [17-23]. Calcination has been widely adopted to increase the reactivity of clay, utilizing temperatures up to $1000{ }^{\circ} \mathrm{C}$ [24-26]. Mechanical activation has also been proposed to increase reactivity, but the research is not as extensive [27,28]. A number of researchers have reported that reactivity increases due to the pre-heat treatment. $\mathrm{Xu}$ and van Deventer noted that the crystalline phase is transformed into the reactive amorphous phase due to heat treatment [29]. However, if too high, the applied calcination temperature may result in the formation of new crystalline phases that are not reactive [30]. Guo et al. reported that the reactive amorphous phase becomes unreactive if the pre-treatment temperature is over $900{ }^{\circ} \mathrm{C}[31,32]$, while Kong et al. stated that applying a pre-treatment temperature of up to $850^{\circ} \mathrm{C}$ does not have a significant effect on the properties of geopolymers [33]. Poowancum and Horpibulsuk stated that the reactivity of calcined clay to be used is dependent on the duration of calcination [34]. They applied heat up to $600^{\circ} \mathrm{C}$ for 5, 2, and $1 \mathrm{~h}$ and found that a calcination time of $2 \mathrm{~h}$ and a $\mathrm{NaOH}$-to- $-\mathrm{Na}_{2} \mathrm{SiO}_{3}$ ratio of 0.5 provided the optimum strength, which was greater than that of OPC. However, the reactivity of the calcinated precursor was reduced by increased calcination time. It was reported by Ferone et al. that an increase in the dissolution rate of $\mathrm{Si}$ and $\mathrm{Al}$ from clay sediments in an alkaline solution with an increase in temperature resulted in an increase in the compressive strength of the calcinated clay when activated [17]. Zhang and Guo et al. observed that the compressive strength of alkali-activated halloysite was dependent on the calcination temperature [35]. Yamchelou et al. found that a calcination temperature of $550{ }^{\circ} \mathrm{C}$ for $1 \mathrm{~h}$ optimized the specific surface area when compared to higher calcination temperatures. Alkali activation of the calcinated clay achieved a compressive strength in excess of $40 \mathrm{MPa}$ after 28 days [36]. Current research has demonstrated the feasibility of clay as an AAM; however, significant gaps in the literature remain regarding the activation of the low-grade clay in terms of both the calcination process and the suitability of the activators. A wide range of temperature have been utilized for the calcination of clay with different treatment periods. Given the environmental impact from the calcination process, understanding the impact of the calcination regime on performance and minimizing the required energy are imperative for the application of clay as an AAM. To investigate the effect of calcination temperature, two regimes were selected to represent a low-temperature-high-duration regime and a high-temperature-low-duration regime at $120^{\circ} \mathrm{C}$ for $24 \mathrm{~h}$ and at $750^{\circ} \mathrm{C}$ for $5 \mathrm{~h}$, respectively, and the results were compared with those of clay subjected to no calcination.

\section{Significance of Research}

Given the environmental concerns due to the use of cement in the construction industry coupled with a potential reduction in the availability of supplementary waste materials such as fly ash, in the future, the identification of suitable alternative materials with lower environmental impact is imperative. One such alternative material that could be used as a binder for alkali-activated concrete is low-grade clay. This paper reports a study on the development of an alkali-activated clay mortar. To assess the effect of calcination on performance, high-temperature and low-temperature calcination regimes were adopted at $120^{\circ} \mathrm{C}$ 
for $24 \mathrm{~h}$ and at $750{ }^{\circ} \mathrm{C}$ for $5 \mathrm{~h}$, respectively, and the results were compared with those of untreated clay. The feasibility was investigated by varying the activator modulus from 1.0 to 1.75 Alkali Modulus (AM) and dosage of the activator (10\% and $15 \%)$. The optimal mix design was identified, and analytical and chemistry techniques, including XRD, NMR and FT-IR, were employed to provide an understanding of the reaction mechanism involved in the activation and reactivity of the clay.

\section{Experimental Procedure}

\subsection{Materials}

The source binder material used in this experiment is low-grade clay from the Ballarat region of Victoria, Australia. The clay was made into powder using a Ball Mill Grinder Machine. The mill was composed of a total of 15 balls, and 5000 cycles were applied. Ground clay powder was sieved through a $100 \mu \mathrm{m}$ sieve, and the clay passing was used for characterization, pre-treatment, and casting of the mortar specimen. The clay was investigated under three different conditions: natural clay without thermal pre-treatment, clay calcinated at $120^{\circ} \mathrm{C}$ for $24 \mathrm{~h}$, and clay calcinated at $750{ }^{\circ} \mathrm{C}$ for $5 \mathrm{~h}$.

The chemical composition was determined using Bruker Axs S4 Pioneer X-ray fluorescence equipment, as shown in Table 1. The particle size distribution was determined using a Malvern Mastersizer analyzer and the crystalline composition with a Bruker Axs D8 ADVANCE Wide Angle X-ray diffraction (XRD) instrument. XRD analysis was performed at $40 \mathrm{kV}, \mathrm{Cu} \mathrm{K} \alpha=1.54178 \AA$ wavelength, and a scanning range of 2 theta in $5^{\circ}-95^{\circ}$. Sample holders were filled using the front-loading procedure. The data obtained from XRD were interpreted using Bruker-DIFFRAC.EVA software and Rietveld analysis [37,38]. The surface area was determined using the Brunauer-Emmett-Teller method by $\mathrm{N}_{2}$ absorption. The crystalline and amorphous content, specific surface area, and particle size distribution are shown in Table 2.

Table 1. Oxide composition of clay.

\begin{tabular}{cccc}
\hline Oxide (\%) & $\begin{array}{c}\text { Clay Without } \\
\text { Pre-Treatment }\end{array}$ & Clay Pre-Treated at $\mathbf{1 2 0}{ }^{\circ} \mathbf{C}$ & Clay Pre-Treated at $\mathbf{7 5 0}{ }^{\circ} \mathbf{C}$ \\
\hline $\mathrm{Al}_{2} \mathrm{O}_{3}$ & 20.06 & 19.63 & 20.20 \\
$\mathrm{SiO}_{2}$ & 62.13 & 63.57 & 65.50 \\
$\mathrm{CaO}$ & 0.71 & 0.67 & 0.70 \\
$\mathrm{Fe}_{2} \mathrm{O}_{3}$ & 5.54 & 5.17 & 5.35 \\
$\mathrm{~K}_{2} \mathrm{O}$ & 4.41 & 4.11 & 4.15 \\
$\mathrm{MgO}$ & 2.08 & 2.05 & 2.23 \\
$\mathrm{MnO}$ & 0.05 & 0.05 & 0.05 \\
$\mathrm{TiO}$ & 0.91 & 0.85 \\
$\mathrm{P}_{2} \mathrm{O}_{5}$ & 0.90 & 0.30 & 0.31 \\
$\mathrm{LOI}$ & 0.33 & 3.54 & 0.66 \\
$\mathrm{Total}$ & 3.79 & 100.00 & 100.00 \\
\hline
\end{tabular}

Note: LOI = loss on ignition (unburnt carbon content).

Table 2. Amorphous and crystalline content and BET surface area of clay material.

\begin{tabular}{cccc}
\hline Property & $\begin{array}{c}\text { Without } \\
\text { Pre-Treatment }\end{array}$ & Pre-Treated at $\mathbf{1 2 0}{ }^{\circ} \mathbf{C}$ & Pre-Treated at 750 ${ }^{\circ} \mathbf{C}$ \\
\hline Amorphous phase (\%) & 21.6 & 23.8 & 23.1 \\
Crystalline phase (\%) & 78.4 & 76.2 & 76.9 \\
Surface Area $\left(\mathrm{m}^{2} / \mathrm{g}\right)$ & 12.45 & 8.66 & 6.03 \\
$\mathrm{D}_{(10)} \mu \mathrm{m}$ & 3.00 & 4.25 & 5.23 \\
$\mathrm{D}_{(50)} \mu \mathrm{m}$ & 14.76 & 17.03 & 22.41 \\
$\mathrm{D}_{(90)} \mu \mathrm{m}$ & 77.88 & 65.18 & 66.75 \\
\hline
\end{tabular}

The alkali activator used was a combination of commercial sodium hydroxide (15 M) solution, supplied by Science Supply Australia Pty Ltd. and grade D sodium silicate solution, supplied by PQ Australia Pty Ltd., with a specific gravity of 1.53 and alkaline modulus of 2 , where $\mathrm{Na}_{2} \mathrm{O}=14.7 \%, \mathrm{SiO}_{2}=29.4 \%$, and $\mathrm{H}_{2} \mathrm{O}=55.9 \%$ by mass. Local river sand from Victoria, Australia, with a fineness modulus of 2.6 was used as fine aggregate. The fine aggregate was prepared in accordance with AS 1141.5 [39]. 


\subsection{Mix Design}

The proportioning of ingredients was calculated based on the mix design of Adam [10,40]. The mass ratio of sand to binder was fixed at 2.75 [41]. The $\mathrm{w} / \mathrm{s}$ (water/solid) ratio was maintained between 0.37 to 0.45 to maintain workability. The quantity of water in the mix is calculated as the sum of the water contained in the sodium silicate, sodium hydroxide, and the added water, while the solid is the sum of the mass of clay and the solid contained in the alkaline activator solution. A number of alkaline activators with a range of concentrations have been used to activate aluminosilicate precursor materials. A combination of sodium hydroxide and sodium silicate has been shown to provide a high capacity for the dissolution of these aluminosilicates and is adopted in this study [42]. Previous research has also identified the activator modulus (AM) and dosage key factors in determining performance [43]. In this study, four activator moduli (AMs) (1.0, 1.25, 1.5 , and 1.75) for each of the two sodium oxide $\left(\mathrm{Na}_{2} \mathrm{O}\right)$ dosages of $10 \%$ and $15 \%$ were selected, corresponding to the optimal range in accordance with previous studies [36,44]. A curing temperature of $120^{\circ} \mathrm{C}$ was employed, as this had been identified as optimum curing temperature in earlier studies [44]. The specific mix designs are given in Table 3.

Table 3. Mix designs of alkali-activated clay mortar $\left(\mathrm{kg} / \mathrm{m}^{3}\right)$.

\begin{tabular}{ccccccc}
\hline Dosage (\%) & AM & Clay & Sand & $\mathbf{N a}_{2} \mathbf{S i O}_{3}$ & $\mathbf{N a O H}$ & Added Water \\
\hline \multirow{4}{*}{15} & 1.00 & 493 & 1356 & 251 & 118 & 34.5 \\
& 1.25 & 493 & 1356 & 315 & 87 & 21.5 \\
& 1.50 & 493 & 1356 & 377 & 56.5 & 9 \\
& 1.75 & 493 & 1356 & 438 & 30.5 & 0 \\
\hline \multirow{2}{*}{10} & 1.00 & 493 & 1356 & 168 & 77 & 84 \\
& 1.25 & 493 & 1356 & 210 & 56.5 & 75.5 \\
& 1.50 & 493 & 1356 & 251.5 & 36 & 66.5 \\
& 1.75 & 493 & 1356 & 296 & 20 & 58 \\
\hline
\end{tabular}

\subsection{Specimen Preparation and Curing}

The solids, clay, and sand were mixed for 4 min using 5-L Hobart mixer. The activator comprising a combination of 15 molar- $\mathrm{NaOH}$ solution and grade $\mathrm{D}$ liquid $\mathrm{Na}_{2} \mathrm{SiO}_{3}$ of $1.52 \mathrm{~g} / \mathrm{cc}$ density with composition of $14.7 \% \mathrm{Na}_{2} \mathrm{O}, 29.4 \% \mathrm{SiO}_{2}$, and $55.90 \%$ water was premixed $15 \mathrm{~min}$ before the additional water was added to the activator solution. This activator solution was then added to the mixture of clay powder and sand. After manual mixing for $1 \mathrm{~min}$, the entire mix was blended at $150 \mathrm{rev} / \mathrm{min}$ for $4 \mathrm{~min}$ and then $300 \mathrm{rev} / \mathrm{min}$ $2 \mathrm{~min}$. The mix was then placed in $50 \times 50 \times 50 \mathrm{~mm}$ Teflon molds followed by $30 \mathrm{~s}$ vibration on a vibrating table. After $24 \mathrm{~h}$ at room temperature, the specimens were cured oven at $120^{\circ} \mathrm{C}$ for a further $24 \mathrm{~h}$. The specimens were then demolded and cured at room temperature until testing.

\subsection{Testing}

Compressive strength measurements of mortars were performed on a Technotest TCM testing machine in accordance with ASTMC109/C109M (2013), with a loading rate of $0.34 \mathrm{~N} / \mathrm{mm}^{2} / \mathrm{S}$ [41]. Three cubes were tested for each data point and testing undertaken at $7,14,28$, and 40 days. A Perkin-Elmer-Spectrum 100 FT-IR spectrometer, with an advanced atmospheric compensation algorithm to remove spectral interferences due to $\mathrm{H}_{2} \mathrm{O}$ and $\mathrm{CO}_{2}$, was utilized to record the FT-IR absorption spectra using a total of 64 scans. The recording ranged from 4000 to $450 \mathrm{~cm}^{-1}$ with a universal attenuated total reflectance (ATR) top plate and diamond crystal. The absorption spectra were logged at a resolution of $4 \mathrm{~cm}^{-1}$ and a scan speed of $0.2 \mathrm{~cm} / \mathrm{s}$. The sample preparation consisted of mixing $2 \mathrm{~g}$ of powdered material with $10 \mathrm{~g}$ of sodium tetrahydroborate. The initial background scan consisted of $100 \%$ sodium tetrahydroborate. Magic-angle spinning solid-state nuclear magnetic resonance (MAS SS NMR) spectra were recorded on an Agilent DD2 $500 \mathrm{MHz}$ NMR spectrometer equipped with a $4 \mathrm{~mm}$ MAS solid-state triple-resonance probe with 
a $10 \mathrm{kHz}$ sample spin rate. ${ }^{27} \mathrm{Al}$ spectra were acquired using the "onepul" method with 256 scans, a 3 s delay time, a 40 ms acquisition time, 30 gain, and a line broadening of 150 . The crystalline and amorphous contents of the clays were determined using Diffrac Eva software. The powdered material was prepared by grinding the mortar samples to pass a 75-micron sieve.

\section{Results and Discussion}

The calcination of the clay had no significant effect on the chemical composition of the material (Table 1), with the $\mathrm{SiO}_{2}$ content being approx. $62 \%-65 \%$ and that of $\mathrm{Al}_{2} \mathrm{O}_{3}$ being approx. $20 \%$. The amorphous content increased with calcination from $21.6 \%$ to $23.8 \%$ at a temperature of $120^{\circ} \mathrm{C}$. However, a small decrease in the amorphous content was observed when heated to $750^{\circ} \mathrm{C}$; this may be due to recrystallization of the amorphous phase at this temperature [22,36]. The calcination reduced the surface area from $12.45 \mathrm{~m}^{2} / \mathrm{g}$ in the raw clay to $6.03 \mathrm{~m}^{2} / \mathrm{g}$ in the clay treated at $750{ }^{\circ} \mathrm{C}$, but the $\%$ passing at both 10 and $50 \mu \mathrm{m}$ increased. The research conducted by Wang et al. (2004) supports this finding; their research suggests that adsorbed water is completely removed at these temperatures, causing shrinkage and disintegration of soil particles, and, hence, a slight reduction in particle size occurs [45]. The minimal increase in amorphous content at both $120^{\circ} \mathrm{C}$ and $750{ }^{\circ} \mathrm{C}$ indicates that these calcination regimes did not increased the amorphous content significantly and that a calcination temperature between this range may be appropriate to optimize the amorphous content.

\subsection{Effect of Activator}

Initial trials on the effect of the activator dosage and modulus were undertaken on the clay pre-treatment at $120^{\circ} \mathrm{C}$. This was selected as the amorphous content and surface area, identified as key parameters in the performance of AAM, were both higher than the clay pre-treated at $750{ }^{\circ} \mathrm{C}$. The compressive strengths of the $10 \%$ dosage and $15 \%$ dosage specimens are presented in, Figures 1 and 2, respectively, with standard deviation.

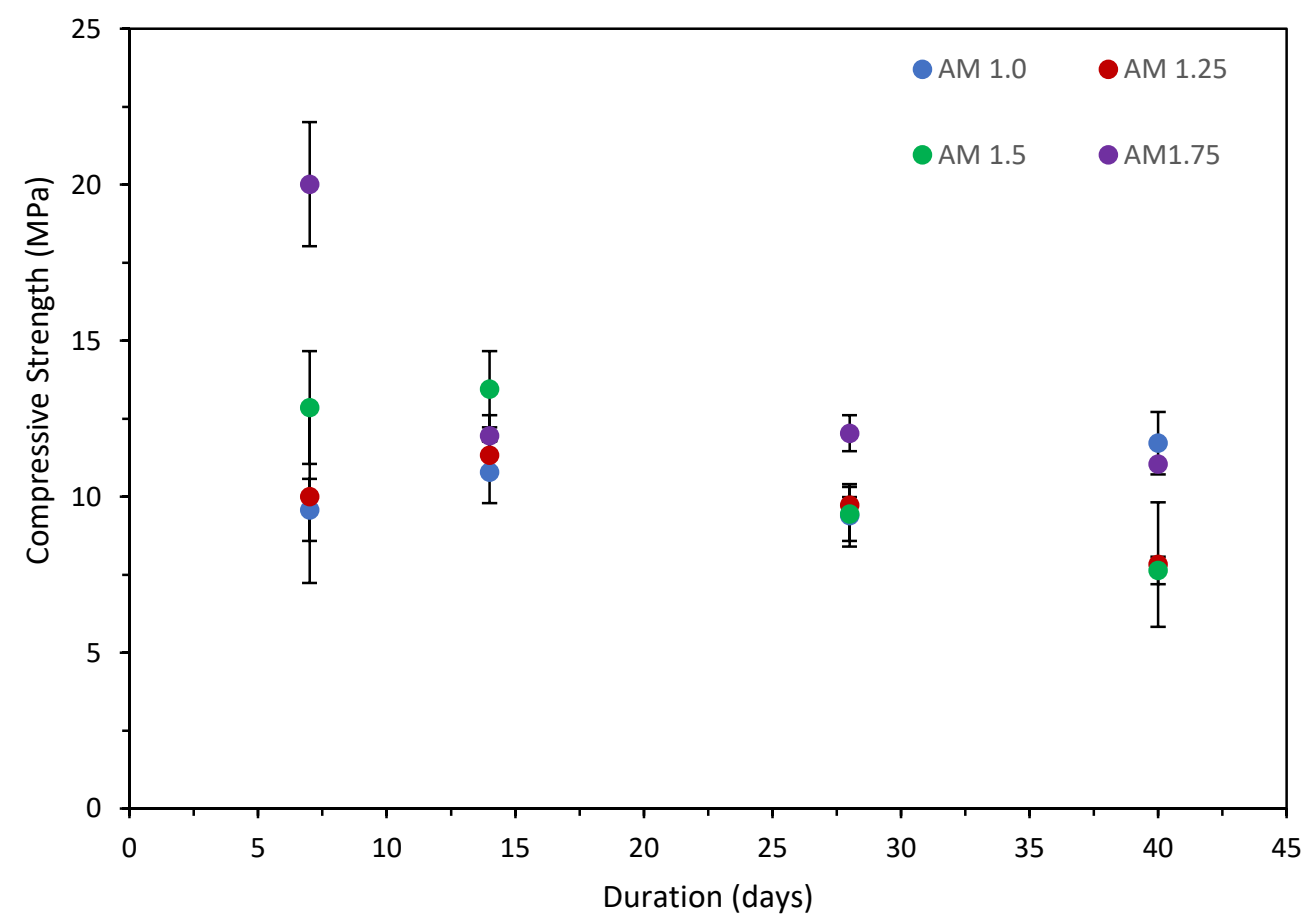

Figure 1. Compressive strength vs. time, $10 \% \mathrm{Na}_{2} \mathrm{O}$ dosage specimens. 


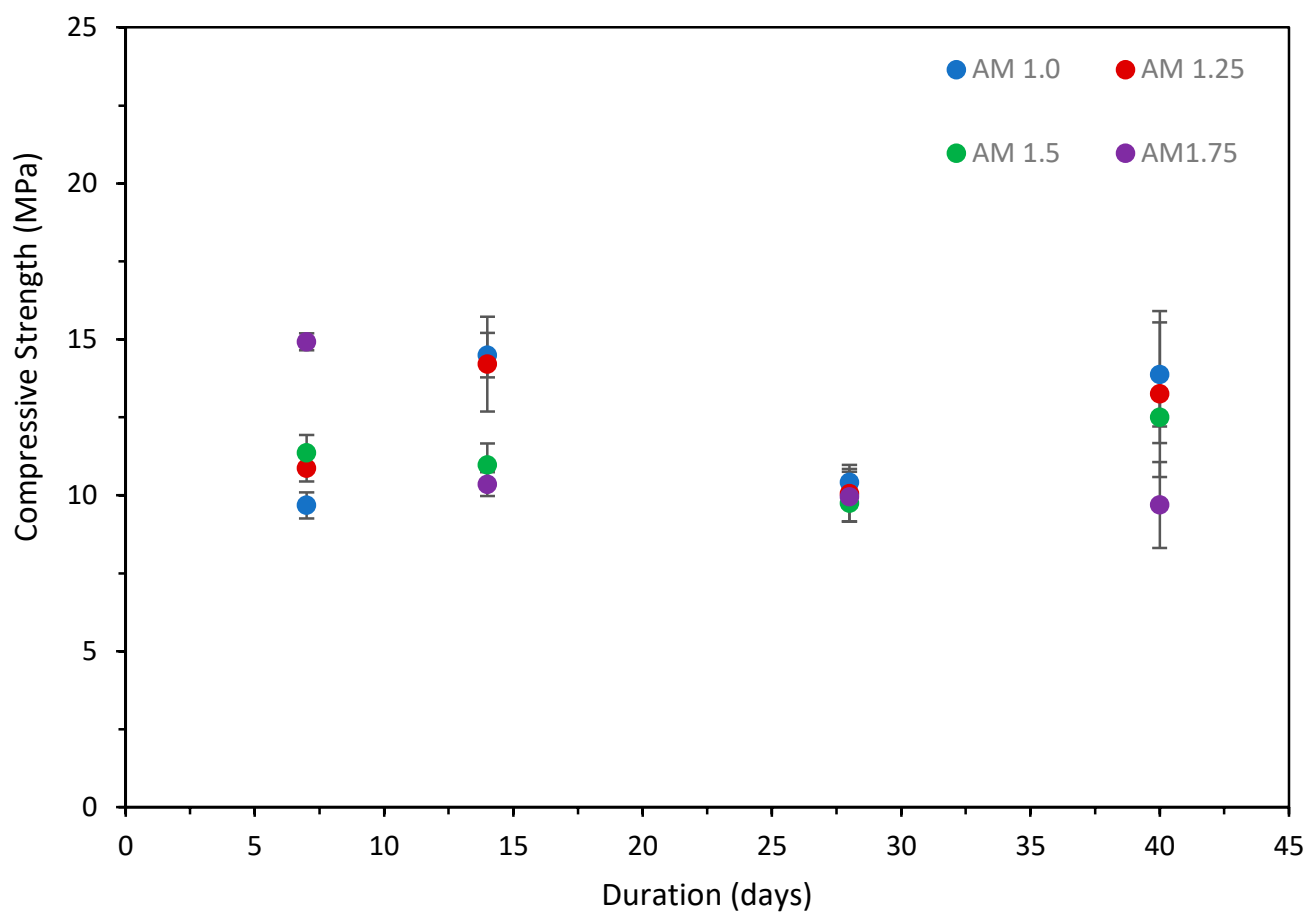

Figure 2. Compressive strength vs. time, $15 \% \mathrm{Na}_{2} \mathrm{O}$ dosage specimens.

The results show that the strength generally increased from 7 to 14 days for both the $10 \%$ and $15 \% \mathrm{Na}_{2} \mathrm{O}$ dosages, excluding the $1.75 \mathrm{AM}$, specimens. A slight decrease in strength was observed in all mortars at 28 days. The results indicate an increase in strength comparable to those observed at 14 days for the 10\% dosage specimens, while the $15 \%$ dosage specimens maintained the strengths observed at 28 days. Additional testing at 40 days was undertaken to determine whether a further reduction in strength was observed. The results indicate an increase in strength comparable to those observed at 14 days for the $10 \%$ dosage specimens, while the $15 \%$ dosage specimens maintained the strengths observed at 28 days. It is hypothesized that due to the low amorphous and aluminosilicate content in the clay, small variations within the pre-cursor material in the batch can have an impact on the strength. Similar behavior has been observed in class $C$ brown coal fly ash with low amorphous and aluminosilicate content [46].

The $\mathrm{Na}_{2} \mathrm{O}$ dosage of $15 \%$ with 7-day compressive strength was highest (20.02 $\mathrm{MPa}$ ) for AM 1.75, whereas AM 1.5 provided the highest strength (13.45 MPa) at day 14 . The $15 \%$ dosage of $1.75 \mathrm{AM}$ achieved maximum strength at day 7 but decreased significantly by day $14(11.96 \mathrm{MPa})$. The compressive strength at day 28 was similar for all specimens, with AM 1.75 achieving the highest strength (12.04 MPa). For the $\mathrm{Na}_{2} \mathrm{O}$ dosage of $10 \%, \mathrm{AM} 1.75$ had the optimum strength at day $7(14.92 \mathrm{MPa})$, whereas AM 1.0 showed optimum strength at days $14(14.5 \mathrm{MPa})$ and $28(10.42 \mathrm{MPa})$, but similar strengths were also achieved by the AM 1.25 specimens. The compressive strengths of all $10 \% \mathrm{Na}_{2} \mathrm{O}$ dosage specimens were greater than the strengths of those of the corresponding $15 \% \mathrm{Na}_{2} \mathrm{O}$ dosage, except for that of AM 1.75. A $\mathrm{Na}_{2} \mathrm{O}$ dosage of $10 \%$ provided consistent strength for all tested AMs; however, all of the specimens prepared with a $\mathrm{Na}_{2} \mathrm{O}$ dosage of $15 \%$ showed a reduction with time.

This behavior has been observed for the fly ash-rice husk bark ash (RHBA) geopolymer, where it was found that the compressive strength of specimens cured at a higher temperature (i.e., $>90^{\circ} \mathrm{C}$ ) started to decrease after a period of time [47]. It was reported that the higher temperature destroyed the granular structure of the geopolymer, which caused dehydration of the geopolymer matrix and excessive shrinkage due to contraction of the geopolymeric gel. Sukmak et al. observed the existence of micro-cracks at an elevated curing temperature $\left(85^{\circ} \mathrm{C}\right)$ with a short curing duration $(24 \mathrm{~h})$, and even at a lower curing temperature $\left(75^{\circ} \mathrm{C}\right)$ with a longer curing duration $(75 \mathrm{~h})$ for clay-fly ash geopolymer 
bricks [48]. Micro-cracking has also been observed in alkali-activated slag geopolymers following elevated curing [49]. Micro-cracking adversely affects the compressive strength due to the breaking of interparticle bonding. This is also supported by the research of Rovnaník, who reported that at lower curing temperatures, the geopolymer matrix developed slowly with lower porosity, while geopolymers formed at higher curing temperatures contained larger pores and a loosely packed structure [50].

The results indicate that the compressive strength was adversely affected by an increase in $\mathrm{AM}$ and dosage, which corresponds to a higher $\mathrm{Na}_{2} \mathrm{O}$ content. It is hypothesized that this may be due to the formation of $\mathrm{Na}_{2} \mathrm{O}-\mathrm{CaO}-\mathrm{SiO}_{2}-\mathrm{H}_{2} \mathrm{O}$, as the solubility of $\mathrm{Na}^{+}$ion is very low in alkali-activated binder materials [51]. To further understand the reaction mechanism underpinning the strength evolution, XRD, FT-IR and MAS-NMR analyses were undertaken on the best-performing compressive strength mixes of AM 1.0 for both the $10 \%$ and $15 \%$ dosages using clay subjected to the three treatment regimes.

\subsection{XRD Analysis}

The XRD spectra are illustrated in Figure 3, and the analysis is presented in Table 4. The principal crystalline components in the raw clay are illite, corresponding with the high $\mathrm{K}_{2} \mathrm{O}$ content, kaolinite, and quartz, with small quantities of rutile $\left(\mathrm{TiO}_{2}\right)$ and chlorite $(\mathrm{MgO})$ present, as well as traces of montmorillonite, albite and, goethite. The amorphous phase is composed primarily of silica, consistent with the relatively high $\mathrm{SiO}_{2}$ content, as shown in Table 1 . After pre-treatment at $120^{\circ} \mathrm{C}$, the kaolinite significantly decreased, and following calcination at $750{ }^{\circ} \mathrm{C}$, none of these remained, as they were completely decomposed to the amorphous phase [52-54]. Illite was also not observed after calcination, and it is surmised that it was converted to muscovite during the calcination process due to dihydroxylation [55]. Muscovite is not observed in the natural clay or when only heated to $120^{\circ} \mathrm{C}$, but the quantity of illite reduced at $120^{\circ} \mathrm{C}$, with a small increase in rutile and chlorite observed together with that in quartz.

Following alkali activation, the primary crystalline phase in all of the mortars was quartz, with similar quantities in all of the $10 \%$ and $15 \%$ mortar specimens, which can be attributed to the presence of sand in the mortar specimens. The amorphous content was reduced following activation; in the $10 \%$ specimens, a significant reduction was observed for the raw clay mortar, with a small 1-2\% reduction noted in the pre-treated specimens. In the $15 \%$ specimens, a similar trend was observed, but the reduction in the raw clay was slightly less than in the raw clay and slightly greater (approx. $8 \%$ lower) in the pre-treated clays.

In addition to the increase in the quartz present, the mortar specimens showed the presence of a number of sodium containing crystalline compounds. Sodalite was identified in all the $15 \%$ dosage mortars and in the pre-treated $10 \%$ specimens, while analcime was evident in the $10 \%$ and $16 \%$ untreated mortars and the $10 \%$ mortar pre-treated at $120{ }^{\circ} \mathrm{C}$. An increase in the albite content was observed in the untreated clay mortar for both the $10 \%$ and $15 \%$ specimens, as well as in the $750^{\circ} \mathrm{C}$ mortars but not in the $120^{\circ} \mathrm{C}$ specimens at both dosages of $10 \%$ or $15 \%$. Furthermore, illite was observed in the $750{ }^{\circ} \mathrm{C}$ mortars, possibly re-converted from the muscovite observed in the calcinated clay. Reduced quantities of illite were detected in the natural and $120^{\circ} \mathrm{C}$ mortars.

All of the mortar specimens showed an increase in crystalline content, suggesting the presence of zeolites rather than an amorphous geopolymeric phase [56,57]. It is hypothesized that the growth of zeolite crystalline phases is supported by the high water content and the employed high curing temperature [58]. Zeolites generally have poor mechanical properties, which could account for the relatively low compressive strengths achieved and the reduction in strength observed in some mixes. 

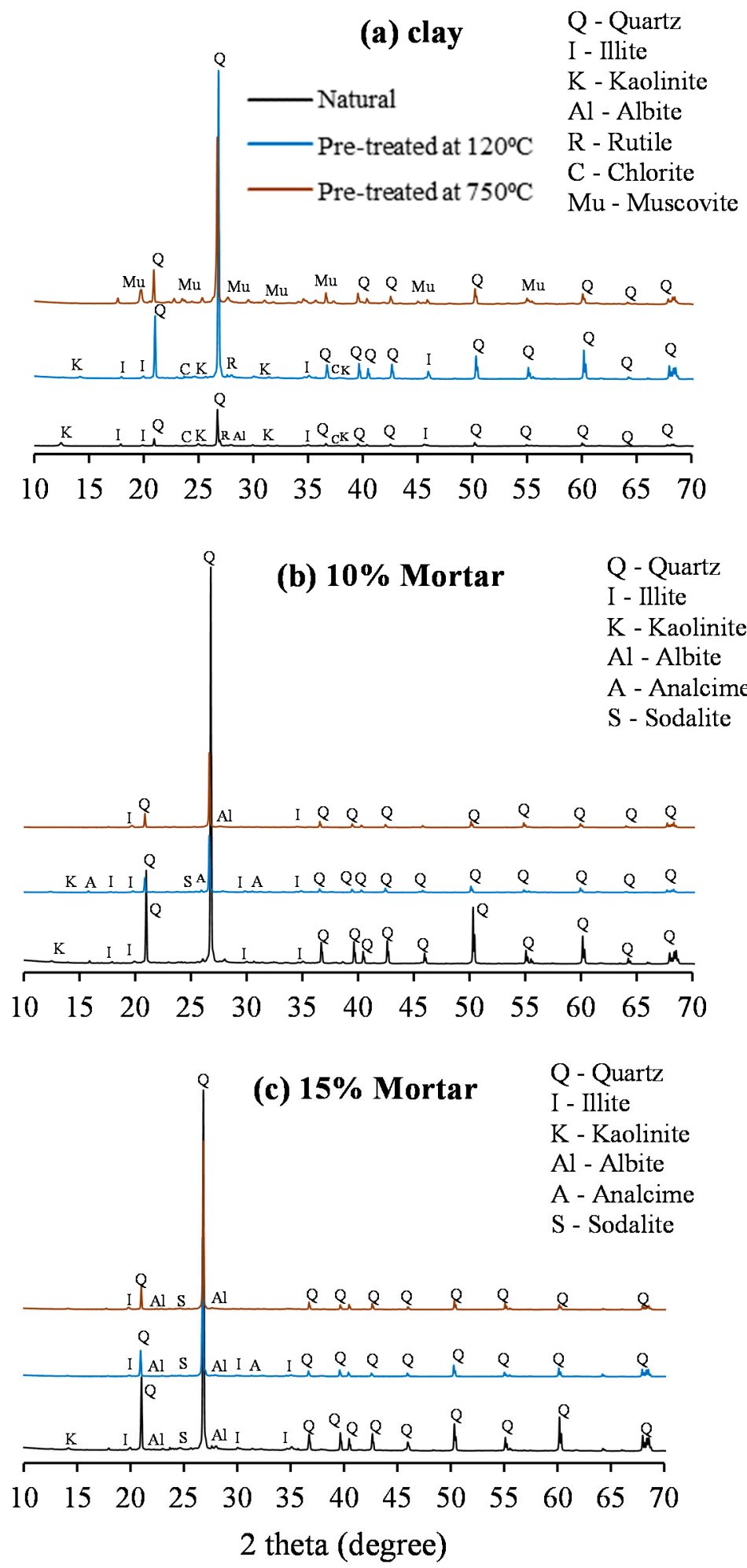

Figure 3. XRD spectra: (a) clay, (b) 10\% mortar, and (c) 15\% mortar. 
Table 4. Mineralogical composition of clay and alkali-activated mortar at 28 days (AM 1.0, dosages of $10 \%$ and $15 \%$ ).

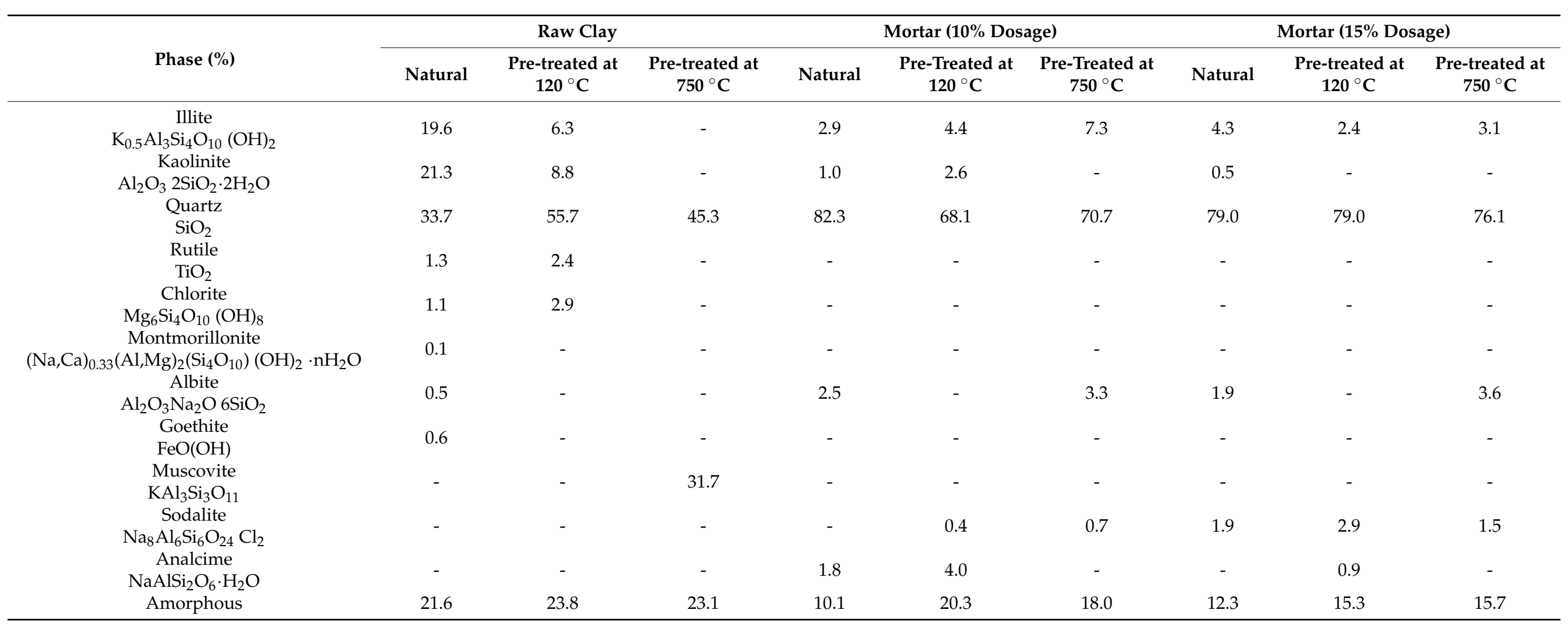




\subsection{NMR Analysis}

The ${ }^{27} \mathrm{Al}$ MAS-NMR spectra of the clays and the mortars at 28 days are presented in Figure 4. The NMR spectra were deconvoluted in accordance with the singular value decomposition method [59]. The calculation of the relative areas of deconvolution lines for the samples is shown in Table 5.

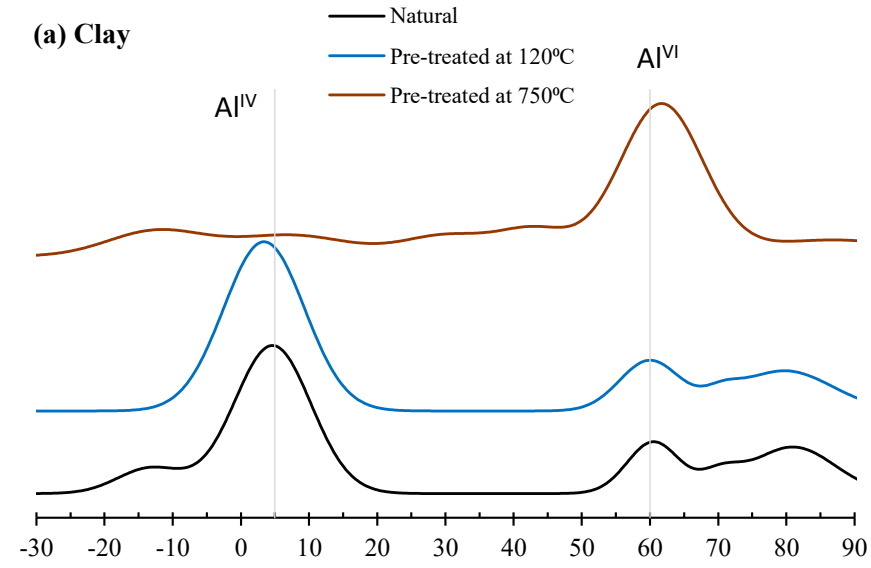

(b) $10 \%$ Mortar

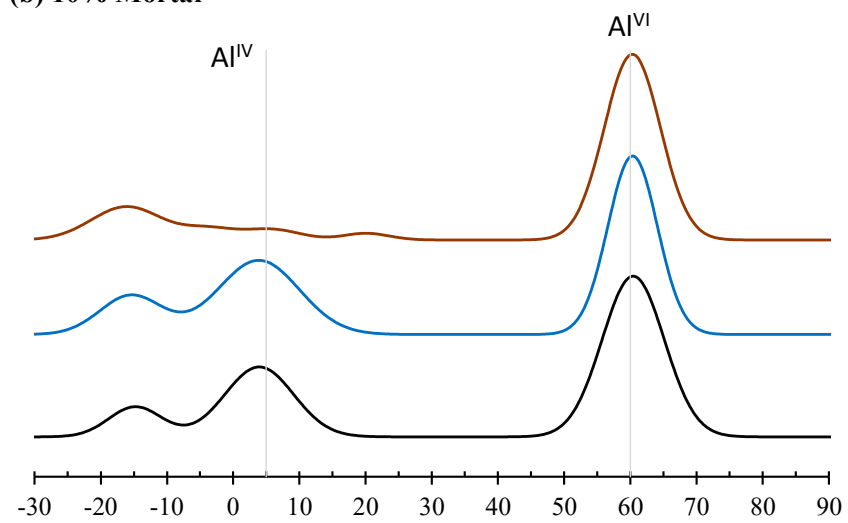

(c) $15 \%$ Mortar

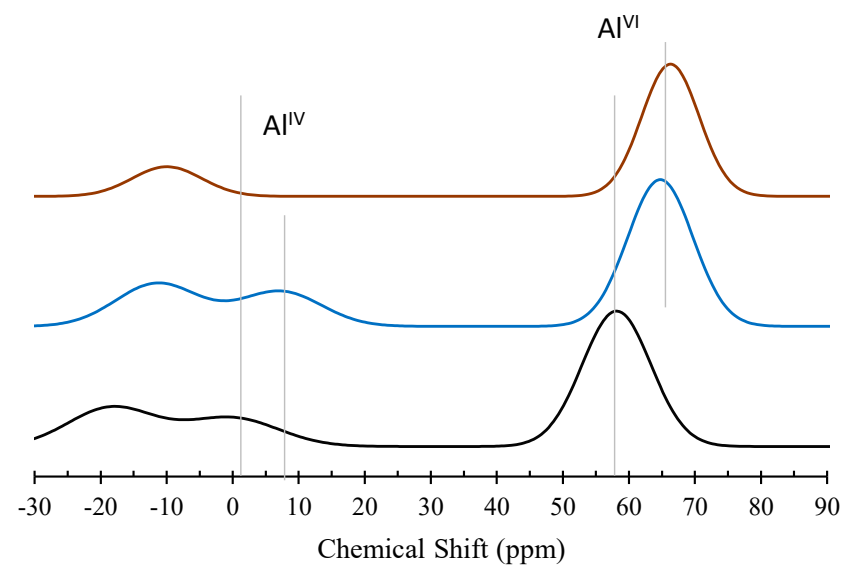

Figure 4. NMR spectra: (a) clay; (b) 10\% mortar and (c) 15\% mortar.

The $\mathrm{Al}$ (IV)-fold coordination is assigned to the chemical shifts in the range between 60 and $80 \mathrm{ppm}$, while $\mathrm{Al}$ (VI) coordination is assigned to the chemical shifts observed between 3.5 and $5.0 \mathrm{ppm}$. For the $10 \%$ dosage specimens, the untreated clay/natural clay powder showed a distinct $\mathrm{Al}(\mathrm{VI})$ coordination peak at $4.8 \mathrm{ppm}$. This shifted to $3.5 \mathrm{ppm}$ 
when clay was pre-treated at $120^{\circ} \mathrm{C}$. No change was noted in the $\mathrm{Al}$ (IV) peaks following treatment at $120^{\circ} \mathrm{C}$. In the clay treated at $750{ }^{\circ} \mathrm{C}$, all of the aluminum was observed to be in the $\mathrm{Al}$ (IV) coordination state, being converted during the calcination process. The deconvoluted data show that the untreated natural clay contained $61.6 \% \mathrm{Al}(\mathrm{VI})$ and $38.4 \%$ $\mathrm{Al}(\mathrm{IV})$. Following pre-treatment of clay at $120^{\circ} \mathrm{C}$, the $\mathrm{Al}(\mathrm{VI})$ coordination increased to $67.6 \%$, with a corresponding decrease in the $\mathrm{Al}$ (IV) coordination, as shown in Table 5. Following activation, the $\mathrm{Al}$ (IV) peaks became sharper, indicating a higher Si content after activation [60]. The resultant natural clay mortar specimens for the $10 \%$ dosage contained $45.5 \% \mathrm{Al}(\mathrm{VI})$ and $54.5 \% \mathrm{Al}(\mathrm{IV})$, and the $120{ }^{\circ} \mathrm{C}$ treated mortars had $38.5 \% \mathrm{Al}(\mathrm{VI})$ and $61.5 \% \mathrm{Al}$ (IV) coordination i.e., the $\mathrm{Al}$ (IV) coordination increased by $16.1 \%$ and $29.1 \%$, respectively. The $15 \%$ mortar specimens displayed increased conversion from $\mathrm{Al}$ (VI) to $\mathrm{Al}$ (IV), the natural clay had $43.8 \% \mathrm{Al}(\mathrm{VI})$ and $56.2 \% \mathrm{Al}(\mathrm{IV})$, and the mortar treated at $120^{\circ} \mathrm{C}$ had $28 \% \mathrm{Al}$ (VI) and $72 \% \mathrm{Al}(\mathrm{IV})$ coordination, corresponding to an increase of $17.8 \%$ and $40.6 \%$, respectively. It has been reported that the quantity of $\mathrm{Al}$ (VI) present in the precursor fly ash-and the conversion of this into $\mathrm{Al}$ (IV) units during reaction process-influences the achieved compressive strength. Hence, the additional conversion from $\mathrm{Al}$ (VI) to $\mathrm{Al}$ (IV) would account for the increase in strength observed in the mortar specimens treated at $120{ }^{\circ} \mathrm{C}$ compared to the natural clay mortar.

Table 5. Relative area and coordination of $\mathrm{Al}(\mathrm{VI})$ and $\mathrm{Al}(\mathrm{IV})$ of clay and alkali-activated mortar at 28 days (AM 1.0, dosages of $10 \%$ and $15 \%$ ).

\begin{tabular}{ccccccc}
\hline \multirow{2}{*}{ Type } & \multicolumn{2}{c}{ Clay (\%) } & \multicolumn{2}{c}{$\begin{array}{c}\text { Geopolymer } \\
\text { Mortar 10\% (\%) }\end{array}$} & \multicolumn{2}{c}{$\begin{array}{c}\text { Geopolymer } \\
\text { Mortar 15\% (\%) }\end{array}$} \\
\cline { 2 - 7 } & Al (VI) & Al (IV) & Al (VI) & Al (IV) & Al (VI) & Al (IV) \\
\hline Clay without pre-treatment & 61.6 & 38.4 & 45.5 & 54.5 & 43.8 & 56.2 \\
Clay pre-treated at $120^{\circ} \mathbf{C}$ & 67.6 & 32.4 & 38.5 & 61.5 & 28 & 72 \\
Clay pre-treated at $750^{\circ} \mathbf{C}$ & 0 & 100 & 0 & 100 & 0 & 100 \\
\hline
\end{tabular}

It is noted that the rate of change of $\mathrm{Al}$ coordination from (VI) to (IV) is low compared to that of fly-ash-based geopolymerization [61]. The authors found that the conversion of $\mathrm{Al}(\mathrm{VI})$ to $\mathrm{Al}(\mathrm{IV})$ coordination was $45 \%$ in the case of the Gladstone-Fly Ash-based geopolymer, whereas in this study, conversion is less than $30 \%$, excluding that of the $120{ }^{\circ} \mathrm{C} 15 \%$ mortar, which is approx. $40 \%$. This low conversion is identified as one of the reasons that clay-based AAM exhibits lower compressive strength than that of the class F fly-ash-based geopolymer. It is also noted that the $\mathrm{Al}(\mathrm{VI})$ coordination is at $3.5 \mathrm{ppm}$ in the clay powder and shifts to $3.87 \mathrm{ppm}$ in the resultant mortar. This is also a significantly smaller chemical shift that represents a lower rate of chemical reaction taking place in the reaction. This may also be a reason for the longer duration required for alkali-activated clay to achieve structural integrity.

Table 5 shows that natural clay contains $62 \% \mathrm{Al}(\mathrm{VI})$ coordination and that the pretreatment of clay at $750{ }^{\circ} \mathrm{C}$ converted all $\mathrm{Al}$ (VI) coordination to $\mathrm{Al}$ (IV) coordination. Buchwald et al. noted during thermal activation of clay minerals that the Al tetrahedral peak becomes larger and the octahedral peak becomes lower with increasing temperature. They also observed that in the range of $500-800{ }^{\circ} \mathrm{C}$, the whole $\mathrm{Al}$ (VI)-fold coordination converts into $\mathrm{Al}$ (IV) coordination, and with further heating, the octahedral peak disappears [2]. Omegna et al. supported this observation, reporting that octahedrally coordinated aluminum decreases with increasing temperature [62]. They also stated that $\mathrm{Al}$ (VI) coordination converts into $\mathrm{Al}$ (IV) coordination at $673^{\circ} \mathrm{K}$. As stated by Sperinck et al. (2011), the loss of local hydroxyl groups increases with increasing temperature, and this loss of local hydroxyl groups causes structural disorder of the material, which leads to the migration of $\mathrm{Al}(\mathrm{VI})$ coordination into $\mathrm{Al}$ (IV) coordination [63]. In the clay pre-treated at $750{ }^{\circ} \mathrm{C}$, there was no change in the $\mathrm{Al}$ coordination; the whole $\mathrm{Al}(\mathrm{VI})$ coordination was converted into $\mathrm{Al}(\mathrm{IV})$ coordination during clay pre-treatment. 
The NMR data indicate that the conversion of aluminum from octahedral to tetrahedral coordination as well as the quantity of aluminum in the tetrahedral coordination influence the mechanical performance. The data indicate that the more aluminum ions in Al (IV) coordination in the reactive crystalline phases, the more significant the role that dissolution of aluminum plays in the ultimate strength achieved during activation.

\subsection{FT-IR Analysis}

The FTIR spectra of natural clay, clay pre-treated at $120^{\circ} \mathrm{C}$ and $750{ }^{\circ} \mathrm{C}$, and alkaliactivated mortars for AM 1.0 at dosages of $10 \%$ and $15 \%$ are presented in Figure 5.
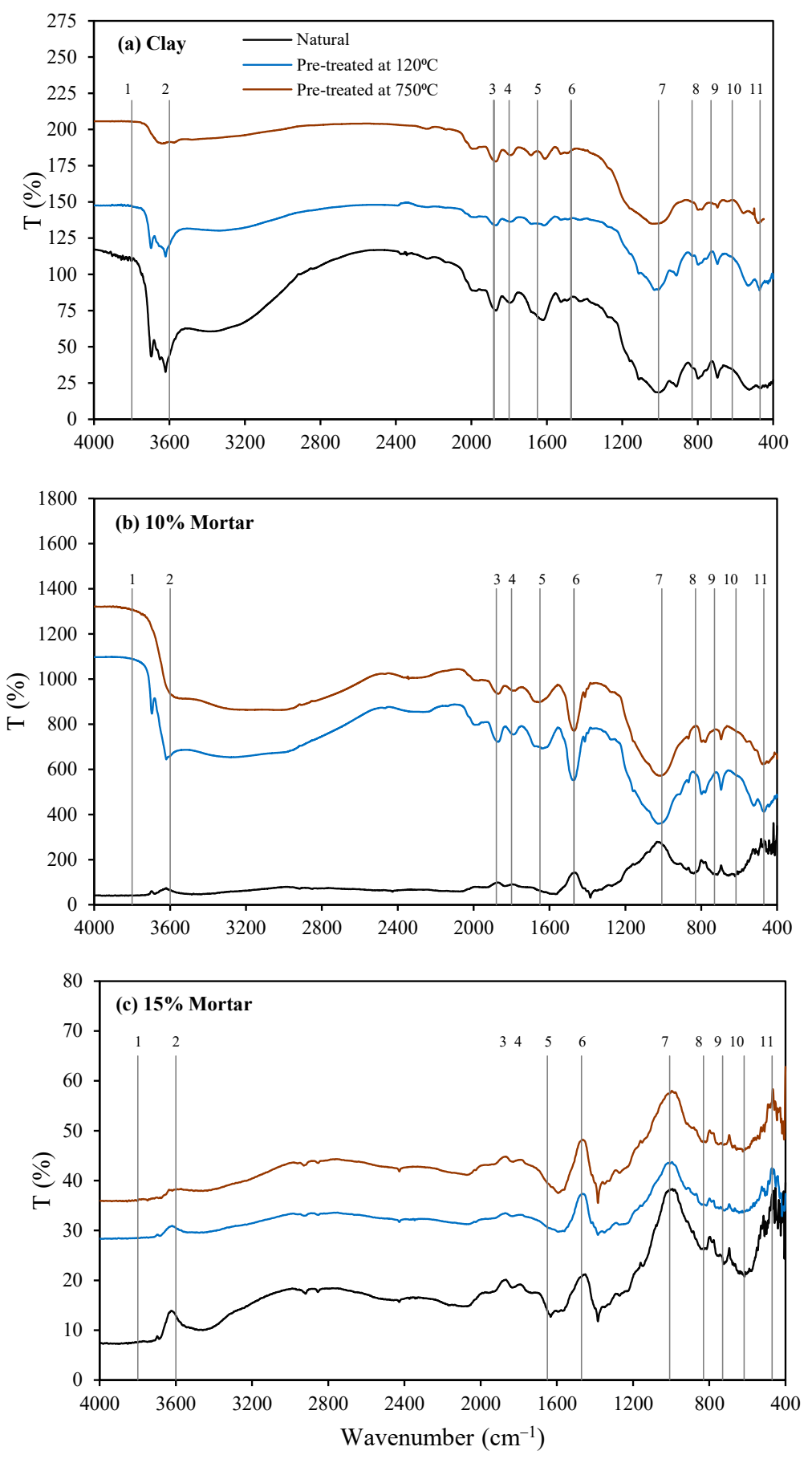

Figure 5. FTIR spectra: (a) clay, (b) 10\% mortar, and (c) 15\% mortar. 
The peaks in the region of $3800-3600 \mathrm{~cm}^{-1}$ present in the untreated clay and clay treated at $120^{\circ} \mathrm{C}$ are attributed to $\mathrm{O}-\mathrm{H}$ stretching and bending vibrations of the hydroxyl groups of kaolinite and illite $[53,64,65]$. These disappear in the spectra of the clay pretreated at $750{ }^{\circ} \mathrm{C}$, which is consistent with the conversion of kaolinite and illite as observed in the XRD data. The peaks observed between 1650 and $1600 \mathrm{~cm}^{-1}$ in the clays are associated with the $\mathrm{H}-\mathrm{O}-\mathrm{H}$ vibrations of absorbed water. These decrease in intensity in both the pre-treated clays compared to the untreated clay, as the water is lost during calcination, while the peaks at 1820 and $1480 \mathrm{~cm}^{-1}$ are identified to be asymmetric $\mathrm{C}-\mathrm{O}$ stretching due to carbonation [54].

The peak at $1008 \mathrm{~cm}^{-1}$ is attributed to $\mathrm{Si}-\mathrm{O}-\mathrm{T}$ (asymmetrical vibration; $\mathrm{T}=\mathrm{Al}, \mathrm{Fe}$, or $\mathrm{Si}$ ), and $1080-1100 \mathrm{~cm}^{-1}$ is attributed to $\mathrm{Si}-\mathrm{O}$ (symmetrical vibrations in $\mathrm{SiO}_{4}$ ) from the kaolinite and illite, as it is not evident in the $750{ }^{\circ} \mathrm{C}$ spectra [13]. The natural clay and clay pre-treated at $120^{\circ} \mathrm{C}$ show a peak at around $850 \mathrm{~cm}^{-1}$, which, in the clay pretreated at $750{ }^{\circ} \mathrm{C}$, shifted to $880 \mathrm{~cm}^{-1}$, while the band at $908 \mathrm{~cm}^{-1}$ for natural clay and $926 \mathrm{~cm}^{-1}$ for clay pre-treated at $120{ }^{\circ} \mathrm{C}$ attributed to $\mathrm{Al}$ (IV)-OH $[64,66]$ disappeared during clay pre-treatment at $750{ }^{\circ} \mathrm{C}$. According to Davidovits (2008), this is due to the transformation of VI-fold coordination of $\mathrm{Al}$ into IV-fold coordination [67]. Furthermore, the VI-fold coordinated $\mathrm{Al}(\mathrm{VI})-\mathrm{OH}$ (stretching vibration) of kaolinite is replaced by the IV-fold coordinated $\mathrm{Al}(1 \mathrm{~V})-\mathrm{O}$ (stretching vibration) due to calcination at $750{ }^{\circ} \mathrm{C}$. This is supported by the XRD, which shows the decomposition of the kaolinite and NMR data that show conversion of $\mathrm{Al}$ from VI to the IV-fold coordination. The doublet in the region of $795-770 \mathrm{~cm}^{-1}$ and the singlet at $695 \mathrm{~cm}^{-1}$ are attributed to Si-O symmetric stretching vibrations from the quartz. The peak at $470 \mathrm{~cm}^{-1}$ could be due to the Si-O in-place bending vibration or Fe-O-T stretching. The band at $540 \mathrm{~cm}^{-1}$ is due to the Si-O-Al (VI) bending vibrations from the kaolinite and illite $[54,57,64]$.

According to Valcke et al. and Zhang et al., the wave range of $1300-800 \mathrm{~cm}^{-1}$ represents $\mathrm{Al}_{2} \mathrm{SiO}_{3}$, where the region between 1300 and $1000 \mathrm{~cm}^{-1}$ represents glassy $\mathrm{Al}_{2} \mathrm{SiO}_{3}$, $1000-900 \mathrm{~cm}^{-1}$ represents glassy (medium) $\mathrm{Al}_{2} \mathrm{SiO}_{3}$, and $900-800 \mathrm{~cm}^{-1}$ represents (high) $\mathrm{Al}_{2} \mathrm{SiO}_{3}[68,69]$ Zhang et al. added that the bonds in the $900-1000 \mathrm{~cm}^{-1}$ region represents the dominant active bond of $\mathrm{Al}_{2} \mathrm{SiO}_{3}$. This is reflected in the broad peak observed in the region between 1100 and $900 \mathrm{~cm}^{-1}$ in the raw clay, indicative of amorphous material [69]. This peak is observed to flatten out further following calcination at $750{ }^{\circ} \mathrm{C}$, correlating with the increase in the amorphous content in the clay after calcination. The FT-IR spectra of all the mortar specimens showed significant peaks between 3800 and $3600 \mathrm{~cm}^{-1}$, clearly showing the presence of water in the mortars. However, there was no evidence of carbonation peaks in the mortar specimens. The $1080-1100 \mathrm{~cm}^{-1}$ peak broadened and shifted to just below $1000 \mathrm{~cm}^{-1}$ for all of the $10 \%$ - and $15 \%$-dosage mortars, while the peaks in the $500-400 \mathrm{~cm}^{-1}$ region also broadened and increased in intensity. The doublet in the region of $795-770 \mathrm{~cm}^{-1}$ and the singlet at $695 \mathrm{~cm}^{-1}$ attributed to Si-O symmetric stretching from the quartz remain consistent with the quartz identified in the XRD analysis. The findings are in agreement with previous research, which reported that shifting of the peaks towards lower wave number is an indication of aluminum incorporation in the back bone of the silicates with the formation of the geopolymer matrix [70]. In addition, peaks are observed with increased intensity and movement to a slightly lower wavelength compared to the unreacted clay (at 1800 and $1450 \mathrm{~cm}^{-1}$ ), which is indicative of carbonation of the mortar.

\section{Summary and Conclusions}

The following conclusions can be drawn from the analysis of the results:

1. The amorphous content of the clay increased from $21.6 \%$ to $23.8 \%$ at $120^{\circ} \mathrm{C}$. However, a small decrease in the amorphous content was observed (23.1\%) when heated to $750^{\circ}$; this is attributed to recrystallization of the amorphous phase at this temperature.

2. The surface area with calcination decreased from $12.45 \mathrm{~m}^{2} / \mathrm{g}$ in the natural clay to $8.66 \mathrm{~m}^{2} / \mathrm{g}$ at $120^{\circ} \mathrm{C}$ and $6.03 \mathrm{~m}^{2} / \mathrm{g}$ at $750{ }^{\circ} \mathrm{C}$, but the $\%$ passing at both 10 and $50 \mu \mathrm{m}$ 
increased. This is attributed to the loss of adsorbed water resulting in shrinkage and disintegration of the soil particles and a reduction in particle size.

3. An increase in strength was observed with calcination of the clay under both $120^{\circ} \mathrm{C}$ for $24 \mathrm{~h}$ and $750{ }^{\circ} \mathrm{C}$ for $5 \mathrm{~h}$.

4. At $120{ }^{\circ} \mathrm{C}$, the specimens with a dosage of $10 \%$ demonstrated improved performance compared to a dosage of $15 \%$, with an AM of 1.0 providing the optimal strength at both dosages.

5. The main components in the raw clay are illite, kaolinite, and quartz with small quantities of rutile and chlorite and traces of montmorillonite, albite, and goethite. Following calcination of the clay, there was a significant reduction in illite and kaolinite at $120^{\circ} \mathrm{C}$, while this was not observed following calcination at $750{ }^{\circ} \mathrm{C}$. Montmorillonite, albite, and goethite all disappeared following calcination, while rutile and calcite content increased at $120^{\circ} \mathrm{C}$, but this was not evident after calcination at $750{ }^{\circ} \mathrm{C}$. The quantity of quartz increased with calcination, while significant quantities of muscovite were observed when calcinated at $750{ }^{\circ} \mathrm{C}$.

6. Calcination at $120{ }^{\circ} \mathrm{C}$ increased the quantity of $\mathrm{Al}(\mathrm{VI})$ from $61 \%$ to $67 \%$, while at $750{ }^{\circ} \mathrm{C}$, all of the $\mathrm{Al}(\mathrm{VI})$ was converted to $\mathrm{Al}(\mathrm{IV})$. Following the reaction, an increase in $\mathrm{Al}$ (IV) was noted for all the mortars, with a higher rate of conversion in the $120^{\circ} \mathrm{C}$ specimens compared to the raw clay. The conversion of $\mathrm{Al}$ (IV) is identified as the primary factor for the increased strength in the treated clay mortars.

7. The mortar specimens showed a broadening of the peak in the region of $1080-1000 \mathrm{~cm}^{-1}$, which was noted together with a shift to lower wavenumbers for all of the $10 \%$ and $15 \%$ dosage mortars. The peaks in the $500-400 \mathrm{~cm}^{-1}$ region also broadened and increased in intensity. The shifting of the peaks towards the lower wave number is an indication of aluminum incorporation in the backbone of the silicates matrix, consistent with the increases in strength observed and the conversion of $\mathrm{Al}$ (VI) to $\mathrm{Al}(\mathrm{IV})$.

The results indicate that it is feasible to use low-grade clay as a precursor material for geopolymer synthesis. However, while the compressive strengths achieved are insufficient for application as structural concrete, they may be suitable for concrete masonry bricks where a minimum strength of $5 \mathrm{MPa}$ is required. The low strength may be a function of the two calcination regimes, where a decrease in surface area was observed for both regimes, with minimal increases in the amorphous content. Hence, it is recommended that future research assess calcination regimes between 120 and $750{ }^{\circ} \mathrm{C}$ to minimize the energy use and to optimize performance. Furthermore, for the application as masonry bricks, research is required on the long-term performance and a lifecycle assessment of the environmental impacts of manufacturing clay-based geopolymers.

Author Contributions: Conceptualization, M.M.R., D.W.L. and I.P.; methodology, M.M.R. and M.T.Y.; validation, D.W.L. and C.G.; formal analysis, M.M.R., D.W.L. and C.G.; investigation, M.M.R. and M.T.Y.; resources, I.P.; data curation, D.W.L.; writing-original draft preparation, M.M.R.; writing-review and editing, D.W.L.; visualization, D.W.L.; supervision, I.P. and D.W.L.; project administration, I.P.; funding acquisition, I.P. All authors have read and agreed to the published version of the manuscript.

Funding: This research received no external funding.

Institutional Review Board Statement: Not applicable.

Informed Consent Statement: Not applicable.

Data Availability Statement: The data presented in this study are available on request from the corresponding author.

Acknowledgments: The X-ray facility, microscopy and microanalysis facility, and scientific and technical assistance provided by RMIT University are further acknowledged. 
Conflicts of Interest: The authors declare that they have no known competing financial interests or personal relationships that could have appeared to influence the work reported in this paper.

\section{References}

1. Hardjito, D.; Wallah, S.E.; Sumajouw, D.M.J.; Rangan, B.V. On the Development of Fly Ash-BasedGeopolymer Concrete. ACI Mater. J. 2004, 101, 467-472.

2. Buchwald, A.; Hohmann, M.; Posern, K.; Brendler, E. The suitability of thermally activated illite/smectite clay as raw material for geopolymer binders. Appl. Clay Sci. 2009, 43, 300-304. [CrossRef]

3. Impacts, A. Vulnerability, Part A: Global and Sectoral Aspects. In Contribution of Working Group II to the Fifth Assessment Report of the Intergovenmental Panel on Climate Change; Climate Change 2014; Cambridge University Press: Cambridge, UK; New York, NY, USA, 2014.

4. Heath, A.; Paine, K.; McManus, M. Minimising the global warming potential of clay based geopolymers. J. Clean. Prod. 2014, 75, 75-78. [CrossRef]

5. IEA. Global Status Report for Buildings and Construction; IEA: Paris, Franch, 2019.

6. Pacheco-Torgal, F.; Castro-Gomes, J.; Jalali, S. Alkali-activated binders: A review. Part 2. About materials and binders manufacture. Constr. Build. Mater. 2008, 22, 1315-1322. [CrossRef]

7. Bernal, S.A.; de Gutierrez, R.M.; Provis, J.L. Engineering and durability properties of concretes based on alkali-activated granulated blast furnace slag/metakaolin blends. Constr. Build. Mater. 2012, 33, 99-108. [CrossRef]

8. Adak, D.; Mandal, S. Strength and Durability Performance of Fly Ash-Based Process-Modified Geopolymer Concrete. J. Mater. Civ. Eng. 2019, 31, 04019174. [CrossRef]

9. Puertas, F.; Fernandez-Jimenez, A. Mineralogical and microstructural characterisation of alkali-activated fly ash/slag pastes. Cem. Concr. Compos. 2003, 25, 287-292. [CrossRef]

10. Law, D.W.; Adam, A.A.; Molyneaux, T.K.; Patnaikuni, I.; Wardhono, A. Long term durability properties of class F fly ash geopolymer concrete. Mater. Struct. 2012, 48, 721-731. [CrossRef]

11. Silva, G.; Kim, S.; Aguilar, R.; Nakamatsu, J. Natural fibers as reinforcement additives for geopolymers A review of potential eco-friendly applications to the construction industry. Sustain. Mater. Technol. 2020, 23, e00132. [CrossRef]

12. Du, W.; Wang, X.; Chen, G.; Zhang, J.; Slany, M. Synthesis, Property and Mechanism Analysis of a Novel Polyhydroxy Organic Amine Shale Hydration Inhibitor. Minerals 2020, 10, 128. [CrossRef]

13. Marsh, A.; Heath, A.; Patereaud, P.; Everenden, M.; Walker, P. Alkali activation behaviour of un-calcined montmorillonite and illite clay minerals. Appl. Clay Sci. 2018, 166, 250-261. [CrossRef]

14. Karozou, A.; Konopisi, S.; Pavlidou, E.; Stefanidou, M. Long-Term Behavior and Durability of Alkali-Activated Clay Mortars. Materials 2020, 13, 3790. [CrossRef] [PubMed]

15. IPCC. 2018: Global Warming of $1.5^{\circ} \mathrm{C}$. In An IPCC Special Report on the Impacts of Global Warming of $1.5^{\circ} \mathrm{C}$ Above Pre-industrial Levels and Related Global Greenhouse Gas Emission Pathways, in the Context of Strengthening the Global Response to the Threat of Climate Change, Sustainable Development, and Efforts to Eradicate Poverty; Masson-Delmotte, V., Zhai, P., Pörtner, H.-O., Roberts, D., Skea, J., Shukla, P.R., Pirani, W.M.-O.A., Péan, C., Pidcock, R., Connors, S., et al., Eds.; IPCC: Geneva, Switzerland, 2019.

16. Perna, I.; Hanzlicek, T.; Supova, M. The identification of geopolymer affinity in specific cases of clay materials. Appl. Clay Sci. 2014, 102, 213-219. [CrossRef]

17. Ferone, C.; Ligouri, B.; Capasso, I.; Colangelo, F.; Cioffi, R.; Cappeletto, E.; Di Maggio, R. Thermally treated clay sediments as geopolymer source material. Appl. Clay Sci. 2015, 107, 195-204. [CrossRef]

18. Diop, M.B.; Grutzeck, M.W.; Molez, L. Comparing the performances of bricks made with natural clay and clay activated by calcination and addition of sodium silicate. Appl. Clay Sci. 2011, 54, 172-178. [CrossRef]

19. Cioffi, R.; Maffucci, L.; Santoro, L. Optimization of geopolymer synthesis by calcination and polycondensation of a kaolinitic residue. Resour. Conserv. Recycl. 2003, 40, 27-38. [CrossRef]

20. Seiffarth, T.; Grone, J.; Slavova, N.; Seigmund, B.; Bhur, H.J.; Ritz, J.P. Effect of thermal pre-treatment conditions of common clays on the performance of clay-based geopolymeric binders. Appl. Clay Sci. 2013, 73, 35-41. [CrossRef]

21. Selemani, S.; Sidiri, A.; Bouaziz, S.; Joussein, E.; Rossognol, S. Effects of metakaolin addition on geopolymer prepared from natural kaolinitic clay. Appl. Clay Sci. 2017, 146, 457-467. [CrossRef]

22. Nikolov, A.; Nugteren, H.; Rostovsky, I. Optimization of geopolymers based on natural zeolite clinoptilolite by calcination and use of aluminate activators. Constr. Build. Mater. 2020, 243, 118257. [CrossRef]

23. Jaya, N.A.; Yun-Ming, L.; Cheng-Yong, H.; Al Bakri, A.M.M.; Hussin, K. Correlation between pore structure, compressive strength and thermal conductivity of porous metakaolin geopolymer. Constr. Build. Mater. 2020, 247, 118257. [CrossRef]

24. Alshaaer, M. Synthesis and characterization of self-healing geopolymer composite. Constr. Build. Mater. 2020, $245,118432$. [CrossRef]

25. Koutník, P.; Soukup, A.; Bezucha, P.; Safar, J.; Kohout, J. Low viscosity metakaolinite based geopolymer binders. Constr. Build. Mater. 2020, 230, 116978. [CrossRef]

26. Khalifaa, A.Z.; Cizera, O.; Pontikes, Y.; Heath, A.; Patereaud, P.; Bernal, S.A.; Marsh, A.T.M. Advances in alkali-activation of clay minerals. Cem. Concr. Res. 2020, 132, 106050. [CrossRef] 
27. Kumar, S.; K, R. Mechanical activation of fly ash: Effect on reaction, structure and properties of resulting geopolymer. Ceram. Int. 2011, 37, 533-541. [CrossRef]

28. Tahmasebi Yamchelou, M.; Law, D.W.; Li, J.; Patnaikuni, I. Alkali activation of mechanically activated low grade clay. J. Sustain. Cem. Based Mater. 2020. [CrossRef]

29. Xu, H.; van Deventer, J.S.J. Microstructural characterisation of geopolymers synthesised from kaolinite/stilbite mixtures using XRD, MAS-NMR, SEM/EDX, TEM/EDX, and HREM. Cem. Concr. Res. 2002, 32, 1705-1716. [CrossRef]

30. Ramezanianpour, A.A. Metakaolin. In Cement Replacement Materials; Springer: Berlin/Heidelberg, Germany, $2014 ;$ pp. $225-255$.

31. Guo, W.; Wu., G.; Wang, J.; Wen, Z.; Sin, S. Preparation and performance of geopolymers. J. Wuhan Univ. Technol. Mater. Sci. Ed. 2008, 23, 326-330. [CrossRef]

32. Guo, X.; Shi, H.; Chen, L.; Dick, W.A. Performance and mechanism of alkali-activated complex binders of high-Ca fly ash and other Ca-bearing materials. In Proceedings of the 3rd World of Coal Ash, WOCA Conference, Lexington, KY, USA, 4 May 2009-7 May 2009.

33. Kong, D.L.Y.; Sanjayan, J.G.; Sagoe-Crentsil, K. Comparative performance of geopolymers made with metakaolin and fly ash after exposure to elevated temperatures. Cem. Concr. Res. 2007, 37, 1583-1589. [CrossRef]

34. Poowancum, A.; Horpibulsuk, S. Development of Low Cost Geopolymer from Calcined Sedimentary Clay. Calc. Clays Sustain. Concr. 2015, 10, 359-364.

35. Zhang, B.; Guo, H.; Yuan, P.; Lia, Y.; Wang, Q.; Deng, L.; Liu, D. Geopolymerization of halloysite via alkali-activation: Dependence of microstructures on precalcination. Appl. Clay Sci. 2020, 185, 105375. [CrossRef]

36. Tahmasebi Yamchelou, M.; Law, D.W.; Brkjaca, R.; Gunasekara, C.; Li, J.; Patnaikuni, I. Geopolymer synthesis using low-grade clays. Constr. Build. Mater. 2020, 268, 121066. [CrossRef]

37. Whitfield, P.S.; Mitchell, L.D. Quantitative Rietveld analysis of the amorphous content in cements and clinkers. J. Mater. Sci. 2003, 38, 4415-4421. [CrossRef]

38. Font, O.; Moreno, N.; Querol, X.; Izquierdo, M.; Álvarez, E.; Diez, S.; Elvira, J.; Antenucci, D.; Nugteren, H.; Plana, F.; et al. X-ray powder diffraction-based method for the determination of the glass content and mineralogy of coal (co)-combustion fly ashes. Fuel 2010, 89, 2971-2976. [CrossRef]

39. Standards Australia. AS411.5-2000 Methods for sampling and testing aggregates, Method 5: Particle density and water absorption of fine aggregate. In AS 1141.5-200 (Australian Standards); Standards Australia: Sydney, Australia, 2000; pp. 1-8.

40. Adam, A.A. Strength and Durability Properties of Alkali Activated Slag and Fly Ash based geopolymer Concrete. Ph.D. Thesis, RMIT University, Melbourne, Australia, 2009.

41. International ASTM. C109/C109M-16a. In Standard Test Method for Compressive Strength of Hydraulic Cement Mortars 2016; ASTM International: West Conshohocken, PA, USA, 2002.

42. Soutsos, M.; Boyle, A.P.; Vinai, R.; Hadjierakleous, A.; Barnett, A.J. Factors influencing the compressive strength of fly ash based geopolymers. Constr. Build. Mater. 2016, 110, 355-368. [CrossRef]

43. Gunasekara, C.; Law, D.W.; Setunge, S. Long term permeation properties of different fly ash geopolymer concretes. Constr. Build. Mater. 2016, 124, 352-362. [CrossRef]

44. Rahman, M.M.; Law, D.W.; Patnaikuni, I. Factors affecting the performance of $100 \%$ clay based geopolymer concrete. In Proceedings of the 28th Biennial National Conference of the Concrete Institute of Australia, Adelaide, Australia, 22-25 October 2017; p. 39.

45. Wang, K.; Shah, S.P.; Mishulovich, A. Effects of curing temeperature and $\mathrm{NaOH}$ addition on hydration and strength development of clinker free CKD-fly ash binders. Cem. Conc. Res. 2004, 34, 229-309. [CrossRef]

46. Khodr, M.; Law, D.W.; Gunasekara, C.; Setunge, S.; Brkjaca, R. Compressive strength and microstructure evolution of low calcium brown coal fly ash-based geopolymer. J. Sustain. Cem. Based Mater. 2019, 9, 17-34. [CrossRef]

47. Nazari, A.; Bagheri, A.; Riahi, S. Properties of geopolymer with seeded fly ash and rice husk bark ash. Mater. Sci. Eng. A Struct. Mater. Prop. Microstruct. Process. 2011, 528, 7395-7401. [CrossRef]

48. Sukmak, P.; Horpibulsuk, S.; Shen, S.L.; Chindaprasirt, P.; Suksiripattanapong, C. Factors influencing strength development in clay-fly ash geopolymer. Constr. Build. Mater. 2013, 47, 1125-1136. [CrossRef]

49. Collins, F.; Sanjayan, J.G. Microcracking and strength development of alkali activated slag concrete. Cem. Concr. Compos. 2001, 23, 345-352. [CrossRef]

50. Rovnanik, P. Effect of curing temperature on the development of hard structure of metakaolin-based geopolymer. Constr. Build. Mater. 2010, 24, 1176-1183. [CrossRef]

51. Garcia-Lodeiro, I.; Palomo, A.; Fernandez-Jimenez, A. Compatibility studies between N-A-S-H and C-A-S-H gels. Study in the ternary diagram Na2O-CaO-Al2O3-SiO2-H2O. Cem. Concr. Res. 2011, 41, 923-931. [CrossRef]

52. Fernandez, R.; Martirena, F.; Scrivener, K.L. The origin of the pozzolanic activity of calcined clay minerals: A comparison between kaolinite, illite and montmorillonite. Cem. Concr. Res. 2011, 41, 113-122. [CrossRef]

53. He, C.L.; Makovicky, E.; Osbaeck, B. Thermal treatment and pozzolanic activity of Na- and Ca-montmorillonite. Appl. Clay Sci. 1996, 10, 351-368. [CrossRef]

54. Kaze, R.C.; Moungam, L.M.B.; Djouka, M.L.F.; Nana, A.; Kamseu, E.; Melo, U.F.C.; Leonelli, C. The corrosion of kaolinite by iron minerals and the effects on geopolymerization. Appl. Clay Sci. 2017, 138, 48-62. [CrossRef] 
55. Msinjili, N.S.; Gluth, G.J.G.; Sturm, P.; Vogler, N.; Khune, H.C. Comparison of calcined illitic clays (brick clays) and low-grade kaolinitic clays as supplementary cementitious materials. Mater. Struct. 2019, 52, 1-14. [CrossRef]

56. Zibouche, F.; Kerdjoudj, H.; d'Espinosede Lacaillerie, J.-B.; Van Damme, H. Geopolymers from Algerian metakaolin. Influence of secondary minerals. Appl. Clay Sci. 2009, 43, 453-458. [CrossRef]

57. Abdullah, M.M.A.B.; Mimg, L.Y.; Yong, H.C.; Tahir, M.F.M. Clay-Based Materials in Geopolymer Technology. In Cement Based Materials; Intechopen: London, UK, 2018; pp. 239-264.

58. Provis, J.L.; Lukey, G.C.; van Deventer, J.S.J. Do geopolymers actually contain nanocrystalline zeolites? A reexamination of existing results. Chem. Mater. 2005, 17, 3075-3085. [CrossRef]

59. Ulcina, K.; Strepankova, H.; Rimal, V.; Hanzlitec, T.; Perna, I. NMR Study of aluminium Coordination in Clays. In WDS'13 22nd Annual Conference of Doctoral Students; MATFYZPRESS: Prague, Czech Republic, 2013; pp. 104-109.

60. Matsuda, A.; Naruyama, I.; Meawad, A.; Pareek, S.; Araki, Y. Reactions, Phases and Microstructure of Fly Ash based AlkaliActivated Materials. J. Adv. Concr. Technol. 2019, 17, 93-101. [CrossRef]

61. Gunasekara, C.; Law, D.W.; Setunge, S.; Burgar, I.; Brkjaca, R. Effect of Element Distribution on Strength in Fly Ash Geopolymers. ACI Mater. J. 2017, 114, 795-808. [CrossRef]

62. Omegna, A.; van Bokhoven, J.A.; Prins, R. Flexible Aluminum Coordination in Alumino-Silicates. structure of Zeolites H-USY and Amorphous Silica-Alumina. J. Phys. Chem. B 2003, 107, 8854-8860. [CrossRef]

63. Sperinck, S.; Raiteri, P.; Marks, N.; Wright, K. Dehydroxylation of kaolinite to metakaolin-a molecular dynamics study. J. Mater Chem. 2011, 21, 2118-2125. [CrossRef]

64. Tchakoute, H.K.; Melele, S.J.K.; Djamen, A.T.; Kaze, C.R.; Kamseu, E.; Nanseu, C.N.P.; Leonelli, C.; Ruscher, C.H. Microstructural and mechanical properties of poly(sialate-siloxo) networks obtained using metakaolins from kaolin and halloysite as aluminosilicate sources: A comparative study. Appl. Clay Sci. 2020, 186, 105448. [CrossRef]

65. Slaný, M.; L, J.; Madejová, J. Structural characterization of organo-montmorillonites prepared from a series of primary alkylamines salts: Mid-IR and near-IR study. Appl. Clay Sci. 2019, 176, 11-20. [CrossRef]

66. van Jaarsveld, J.G.S.; van Deventer, J.S.J.; Lukey, G.C. The effect of composition and temperature on the properties of fly ash- and kaolinite-based geopolymers. Chem. Eng. J. 2002, 89, 63-73. [CrossRef]

67. Davidovits, J. Geopolymer Chemistry and Applications; Geopolymer Institute: Saint Quinten, France, 2008.

68. Valcke, S.L.; Pipilikaki, A.P.; Fischer, H.R.; Verkuijlen, M.H.W.; van Eck, E.R.H. FT-IR and ${ }^{29}$ Si-NMR for evaluating aluminiumsilicate precursors for geopolymers. Mater. Struct. 2014, 48, 557-569. [CrossRef]

69. Zhang, Z.; Wang, H.; Provis, J.L. Quantitative study of the reactivity of fly ash in geopolymerization by FTIR. J. Sustain. Cem. Based Mater. 2012, 1, 154-166. [CrossRef]

70. Phair, J.W.; van Deventer, J.S.J. Effect of silicate activator $\mathrm{pH}$ on the leaching and material characteristics of waste-based inorganic polymers. Miner. Eng. 2001, 14, 289-304. [CrossRef] 